\title{
Groundwater Management at West El-Minia Desert Area, Egypt Using Numerical Modeling
}

\author{
Ahmed A. Abdel Moneim1', José Paulino Fernández-Álvarez², Elsayed M. Abu El Ella3, \\ Ahmed M. Masoud ${ }^{*}$ \\ ${ }^{1}$ Geology Department, Faculty of Science, Sohag University, Sohag, Egypt \\ ${ }^{2}$ Hydro-Geophysics and NDT Modeling Unit, Polytechnic School of Mieres, University of Oviedo, Mieres, Spain \\ ${ }^{3}$ Geology Department, Faculty of Science, Assiut University, Assiut, Egypt \\ Email: "ahmed.masoud@science.sohag.edu.eg
}

Received 1 June 2016; accepted 22 July 2016; published 25 July 2016

Copyright (C) 2016 by authors and Scientific Research Publishing Inc.

This work is licensed under the Creative Commons Attribution International License (CC BY). http://creativecommons.org/licenses/by/4.0/

(c) (i) Open Access

\section{Abstract}

Water shortage is the main problem facing any development in Egypt especially in the desert lands. River Nile is considered the main source of water in Egypt but its water covers only the area of flood plain where its tributaries do not reach to the desert. The desert fringes, west of El-Minia governorate, Egypt, are areas of natural expansion for agricultural, industrial, and civil activities. This implies an increasing demand for groundwater. A numerical groundwater model is one of the main tools used for assessment of the resource potential and prediction of future impact under different circumstances and stresses. In this paper, a transient groundwater flow model in the desert district west of El-Minia, Egypt, was developed. The conceptual model was built by analyzing the hydrogeological data and previous work. Steady state model of year 1990 was used to investigate and calibrate the parameters such as hydraulic conductivities, recharge and conductance of the surface water streams. The storage coefficients are calibrated by the transient model based on the available data observed from 1990 to 2013, which provides insights to understand the behavior of groundwater system in Quaternary Aquifer and to predict spatial-temporal distributions of groundwater levels and groundwater flow in responding to extraction of water. The calibrated transient model will be used to predict the impacts of desert development schemes and water resources management schemes on groundwater in the study area.

\section{Keywords}

Groundwater Flow Model, El-Minia, Groundwater Management, Quaternary Aquifer

\footnotetext{
${ }^{*}$ Corresponding author.
}

How to cite this paper: Abdel Moneim, A.A., Fernández-Álvarez, J.P., Abu El Ella, E.M. and Masoud, A.M. (2016) Groundwater Management at West El-Minia Desert Area, Egypt Using Numerical Modeling. Journal of Geoscience and Environment Protection, 4, 66-76. http://dx.doi.org/10.4236/gep.2016.47008 


\section{Introduction}

In a typical arid country like Egypt, groundwater is considered one of the most important sources of water for most uses. In the last decades, the development of the desert areas by building up new communities attracted the attention of the decision makers and the investors. This natural expansion for agricultural, industrial and civil activities in the desert areas needs more exploration activities for groundwater resources. This may lead to decline of groundwater level. Monitoring was essential to evaluate the impact of the reclamation. A numerical groundwater model is considered as a good tool to help evaluate this impact and to put different schemes for Groundwater management.

The desert area of West El-Minia is considered the most desert area subjected to reclamation in the past twenty years depending mainly on the groundwater extraction though drilled wells. Quaternary aquifer is the most target aquifer for extraction.

The main goal of the study is to build numerical model for the groundwater flow in the Quaternary aquifer of the study area. Groundwater numerical model is the efficient tool to help characterize the over extraction problem and to help find solutions and help decision makers to better plan the sustainable development in these areas.

The aim of this model is to help characterize the Quaternary Aquifer System in the study area and to investigate changes in the groundwater levels during the time span in response to groundwater extraction and try to find solution for the problem of decline of groundwater in this aquifer.

\section{Study Area}

The study area is an elongated strip located west of River Nile along El-Minia governorate between longitudes $30^{\circ} 25^{\prime} 00^{\prime \prime} \mathrm{E}$ and $30^{\circ} 52^{\prime} 00^{\prime \prime E}$ and latitudes $27^{\circ} 40^{\prime} 00^{\prime \prime} \mathrm{N}$ and $28^{\circ} 40^{\prime} 00^{\prime \prime} \mathrm{N}$, its area amounts to $5300 \mathrm{~km}^{2}$ (Figure 1 ). The area is arid to semi-arid, hot climate, dry, rainless in summer, and mild with rare precipitation in winter. The rainfall average value for the last 15 years ranged from 23.05 to $33.15 \mathrm{~mm} /$ year, while the evapotranspiration at

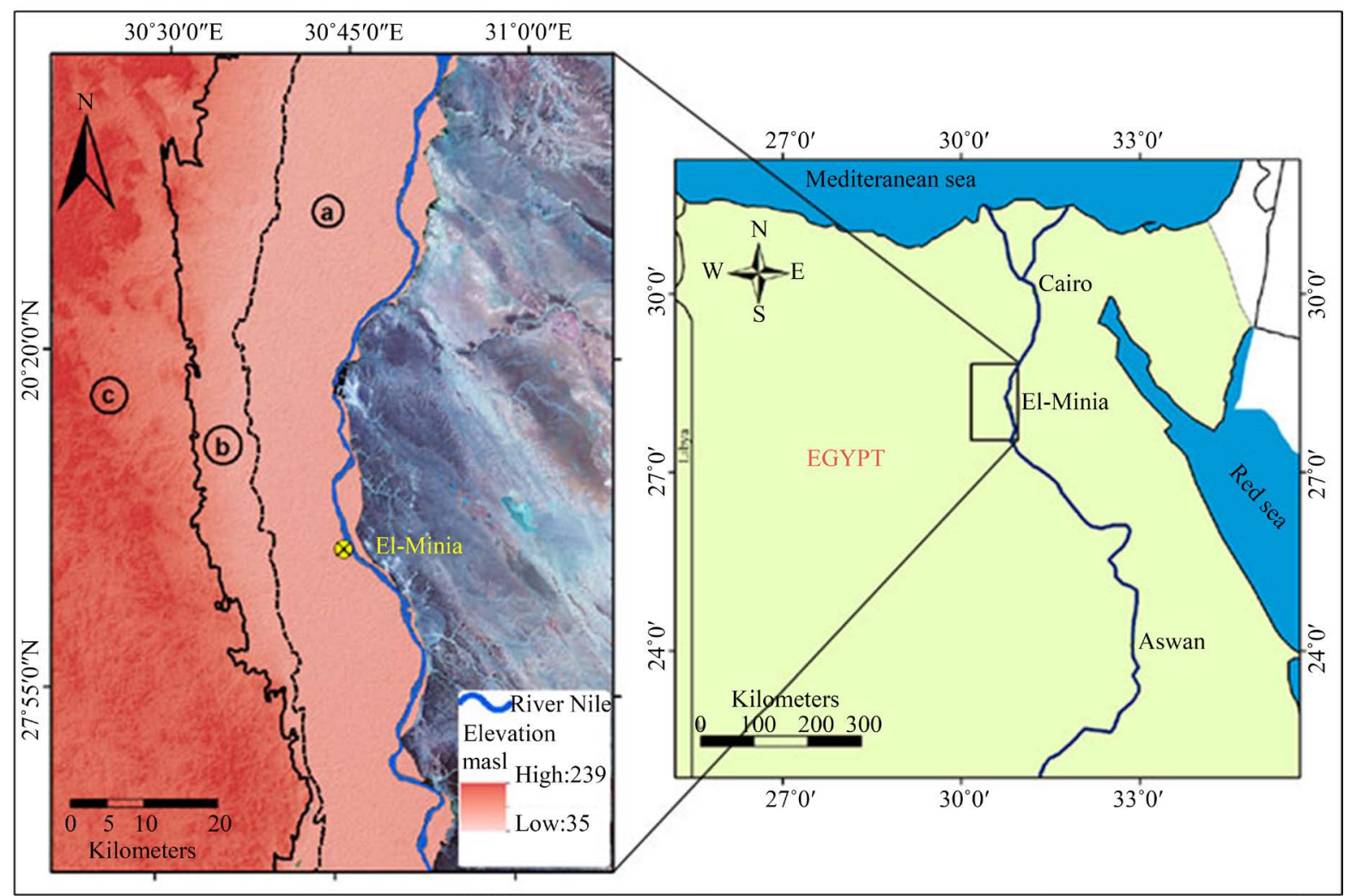

Figure 1. Location, geomorphology and digital elevation model of the study area. (a) Nile flood plain; (b) Desert fringes; (c) Limestone plateau. 
El Minia is $4897.91 \mathrm{~mm} /$ year [1]. The average temperatures during January are $4.5^{\circ} \mathrm{C}$ to $20.5^{\circ} \mathrm{C}$ and $20.5^{\circ} \mathrm{C}$ to $37.7^{\circ} \mathrm{C}$ during August. Relative humidity is varying from $68 \%$ in January to over $70 \%$ in June [2].

The River Nile runs between two high calcareous plateau bounding it to the east and west sloping from south to north with about $0.1 \mathrm{~m} / \mathrm{km}$ [1]. The Nile flow along the eastern part of the Valley; therefore, the cultivated area is wider in the western part than in the east (Figure 1).

\section{Geomorphological and Geological Setting}

Geomorphologically, there are three units dominated in the study area, from west to east as follow (Figure 1):

a) The limestone plateau, is structurally formed, composed mainly of limestone covered with alluvial deposits of sands and gravels and bounds the Nile Valley from the east and west.

b) The old alluvial plain, is adjacent to the cliff of plateau and it includes new desert reclamation lands as well as scattered urbanized areas in the western side of the valley and it is irrigated by groundwater.

c) The young alluvial plain, occupies the area adjacent to the Nile bank between the River Nile and old alluvial plain. It represents the old agricultural areas irrigated with surface water diverted from the Nile and from main canals such as Bahr Yousef. Generally, the land surface drops gently in longitudinal direction (northward) while the lateral slope towards the Nile (eastward) is very high.

The stratigraphic succession in El Minia area is essentially represented by sedimentary rocks (Tertiary and Quaternary). The surface geologic map of the area is shown in Figure 2. The stratigraphic sequence is built-up of from top to base as follows [3]:

a) Holocene deposits represents in Nile Silt, mainly occupied by cultivated land of Nile valley except small areas in extreme west of the valley. Its maximum thickness reaches $15 \mathrm{~m}$ in the middle of the Nile valley. Undifferentiated sediments, recently formed, cover the study area such as sand dunes and Fanglmerates.

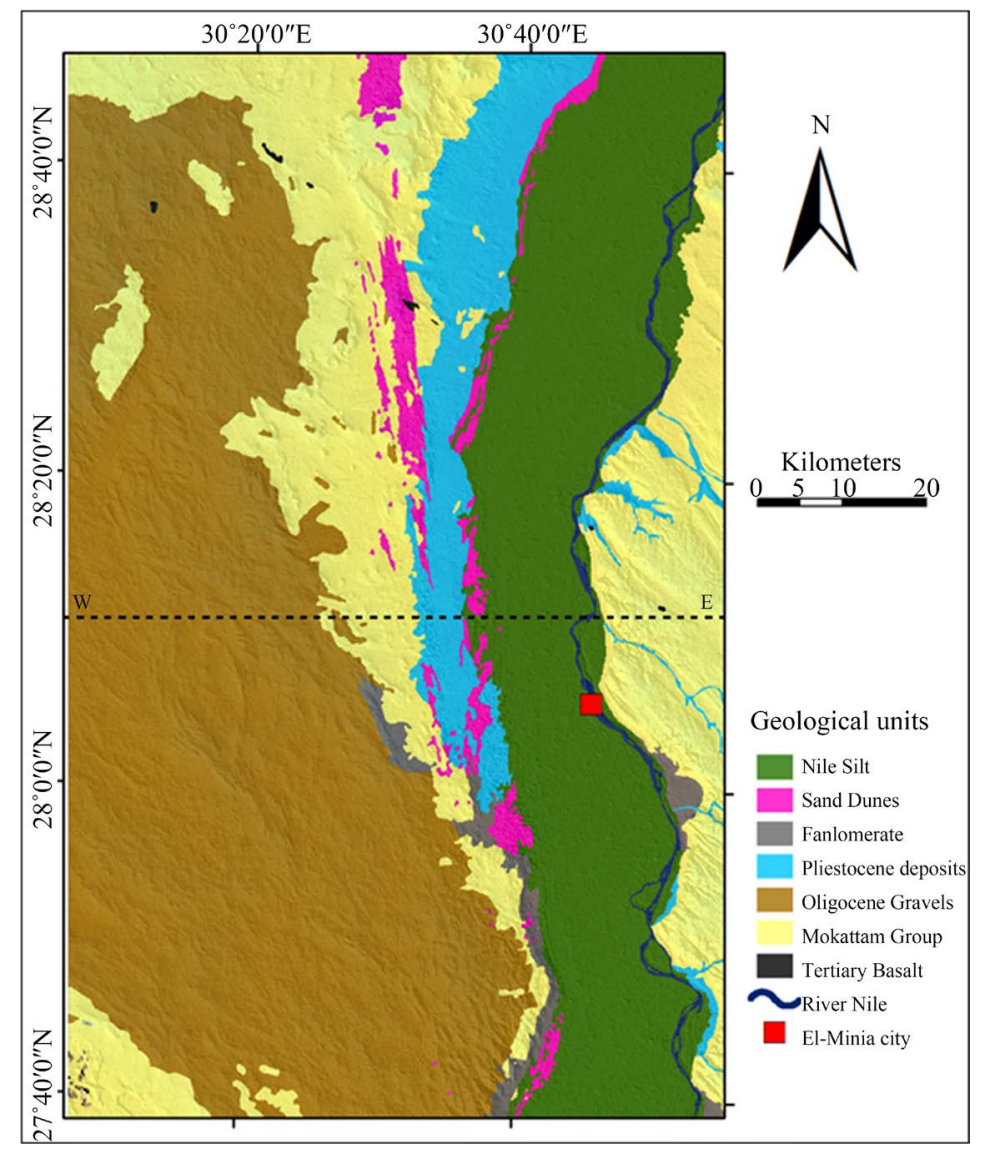

Figure 2. Geological map of the study area (modified after [8]). Line W-E represents a geological cross section in El-Minia area (see Figure 3). 
b) Unconsolidated sands and gravels (Quaternary deposits) intercalated with clay lenses. The thickness increases generally in the direction of the Nile. It is partially saturated with groundwater. Undifferntiated deposits such as sand dunes, wadi deposits and Fanglomerate are distributing in different localities in the area.

c) Pliocene Clay bands, deposited during the transgression of the Pliocene sea into the old eroded valleys of the Eocene limestone plateau [4].

d) Oligocene-Pleistocene gravel and sand, covers a wide area and composed mainly of gravel, sand and limestone fragments varying in size with dark brown color, its maximum thickness reaches $200 \mathrm{~m}$ in the western portion. It is considered as a good local aquifer in the desert fringes.

e) Qatrani Formation of Oligocene, consisting of a sequence of alternating clastics, siltstone and clay stone. It overlay the Eocene limestone and occupied the western part of western plateau.

f) Limestone of Samalut and Minia Formations (Mokattam Limestone group), represent one of the main water bearing formation in the area. It is chalky and dense limestone, contains fissures, fractures, and joints, which all construct the conduits of the groundwater system.

g) Tertiary volcanic basaltic are recorded in some localities in the area. It was detected that the Tertiary volcanic basalts dyke intruded into the chalky limestone aquifer that enhance the interconnection of the, fissures, joint and fracture systems [3].

h) Structurally; the Nile valley is bounded by wrench faults that more or less parallel either to the Gulf of Suez or Gulf of Aqaba directions (Youssef, 1968). They area of normal type trending NW-SE. They play a great role in recharging the Middle Eocene Limestone Aquifer [5].

\section{Hydrogeological Setting}

In the study area, groundwater is considered as a part of the regional Nile valley aquifer systems. Two aquifers are recognized, Quaternary and Eocene aquifer (Figure 3). Quaternary aquifer, has a wide areal extension, especially on the western side of the Nile Valley. The aquifer is formed of a relatively thick formation of Quaternary alluvial deposits composed of sands and gravels intercalated with clay lenses. The aquifer is overlain by Holocene Nile silt and sandy clay extending into a semi-permeable to impermeable layer. The thickness of the Holocene silt and sandy clay layer varies from zero (at the fringes) and 16 meter (near the Nile) with an average thickness of 9 - 10 meter. The top layer receives water from both the infiltration of return flow after irrigation of the agricultural lands and from subsurface seepage through banks and beds of the irrigation canals and conduits. The Quaternary aquifer has a large extension in the north-south direction. It is recorded on an impermeable bed at the bottom which is formed of Pliocene clays. It is limited from the east and west and rests unconformabley on Middle Eocene Limestone [6]. The thickness of the aquifer decrease from $200 \mathrm{~m}$ below the Nile to a few meters towards west and east [7].

The Middle Eocene limestone water bearing formation, underlies the Quaternary aquifer and overlies the Nubian sandstone water bearing formation. The Eocene aquifer occupies the extreme eastern and western sides of the study area. Eocene limestone aquifer unit is represented by Samalut formation and is made up of hard, white,

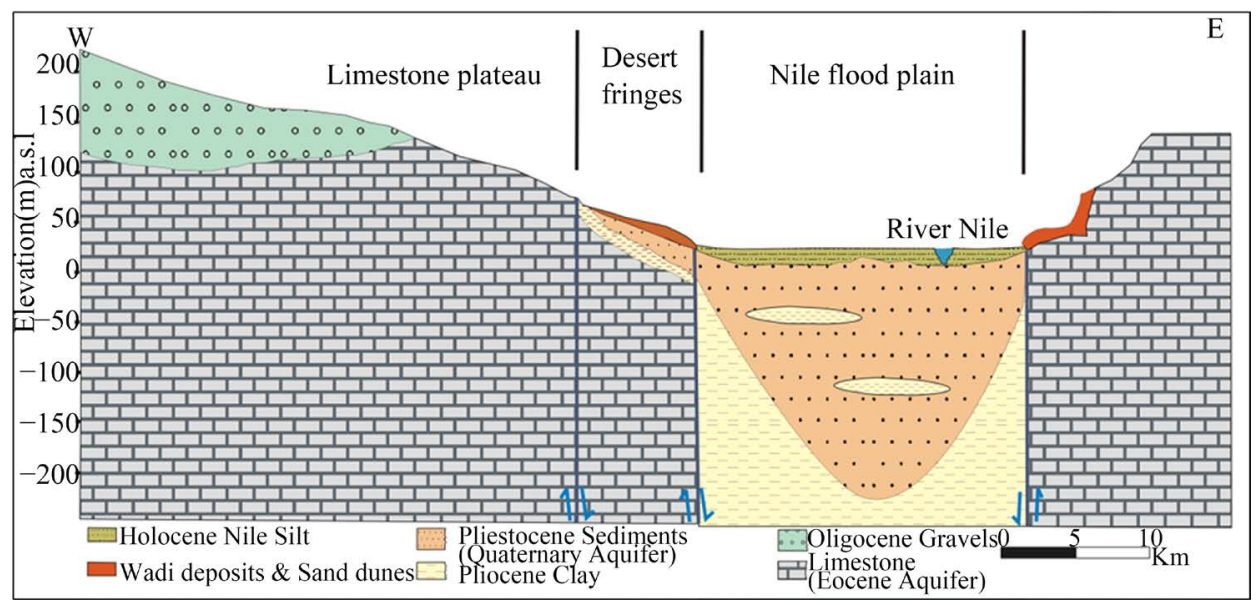

Figure 3. General hydrogeological cross section in El-Minia area [9]. 
highly fossiliferous limestone with shale and marl intercalations. Eocene limestone is fractured and is probably affected by network of faulting system [4].

\section{Methodology}

The strategy is to first simulate the regional flow pattern with a coarse-grid model, then create a second, local-scale model with a finely spaced grid for the area of interest. The models are nested, by taking simulated heads from the regional model and applying these along the edges of the local model as boundary conditions. This strategy, known as telescopic mesh refinement (TMR), reduces the computational burden while providing the necessary detail in the area of interest. The study area is a part of the great desert area west of El-Mina governorate. In the present study, the regional model include the desert area West of El-Minia governorate while local model represent the development area which named "West El-Minia" area.

The three-dimensional groundwater flow computer code (MODFLOW) has been used for numerical modeling of the groundwater flow regime in the study area. The MODFLOW software is originally developed by the US Geological Survey (USGS) in the 1980s [10]. MODFLOW is able to simulate steady state and transient flow conditions in one, two and three dimensions. Some model assumptions are stated as that: The density of the fluid is constant; water movement can be in three (orthogonal) directions ( $\mathrm{x}, \mathrm{y}, \mathrm{z}$ ) and properties within a cell are assumed to be homogeneous.

\section{Conceptual Model}

The regional model extends approximately $127.5 \mathrm{~km}$ in a north-south direction and $45.5 \mathrm{~km}$ in east-west direction. The model is discretized into a uniform grid with square blocks with a side length of $500 \mathrm{~m}$ (UTM WGS 1984, zone 36N 30E). The model grid is designed as 255 rows by 91 columns in each of the model layers. The northern and southern boundaries are represented as specified head boundary condition. It is determined using the known head values in the aquifer obtained from hydrogeological data collected from the previous studies or field works. The eastern and western boundaries are represented by the no-flow conditions. It is represented by the eastern and western calcareous plateau. MODFLOW simulate this type of boundary by assigning inactive cells. The conceptual model of this regional model is shown in Figure 4.

The model grid of the regional model was refined by two where the dimension of each cell in the TMR models was $250 \times 250 \mathrm{~m}$. The initial and boundary conditions for TMR models are obtained from the regional model results. The western boundary is no flow, the eastern, northern and southern boundaries were assigned as constant head boundaries. The TMR models were extended little far from the development areas to maintaining a buffer zone between the area of interest and the edges of the local model in order to avoid the strong effect of

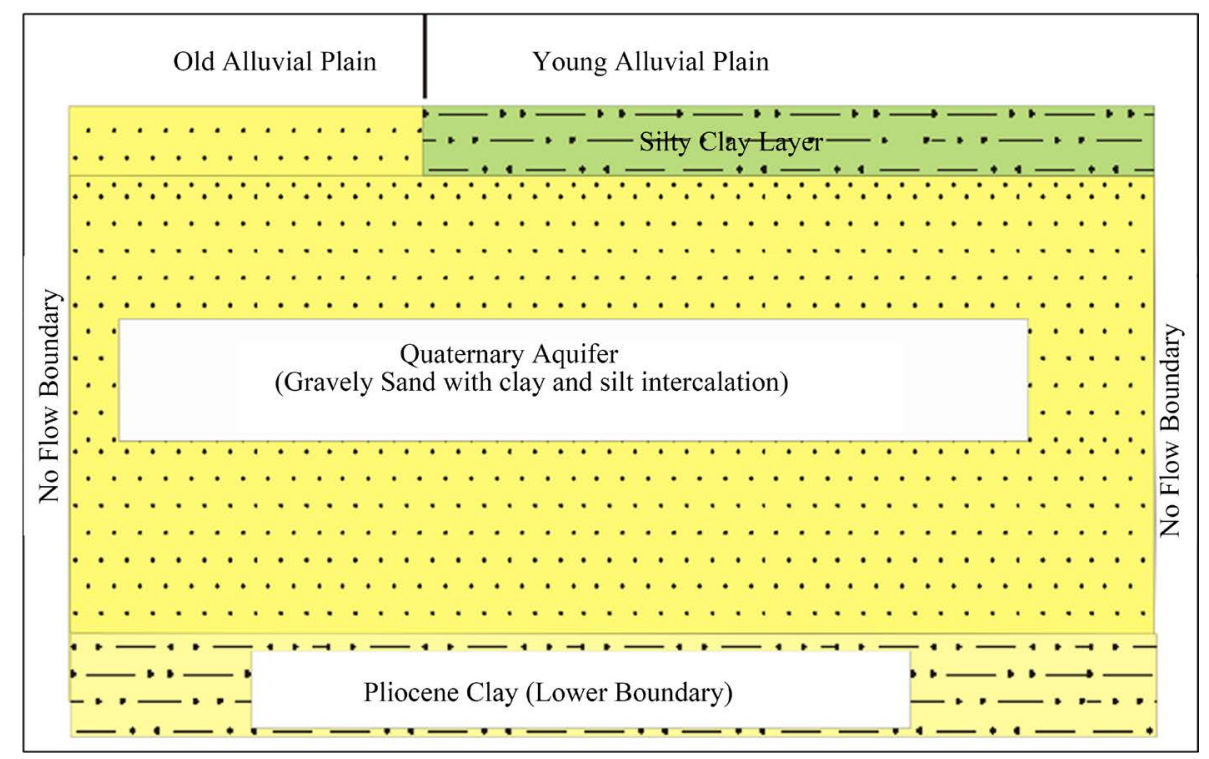

Figure 4. Schematic section showing the conceptual model of Quaternary Aquifer in El-Minia area. 
the constant head boundaries. The pumping wells, the recharge rate and the observation wells for each area are keeping the same as regional model.

Rivers and canals (Rive Nile, Ibrahimia canal, Bahr Youssef canal and irrigation canals) were simulated in the model by general head boundary conditions. The river stage and conductance of the rive cell is the most assigned parameters of any River cell.

Quaternary aquifer is recharged by infiltration from the irrigation distribution system and excess applications of irrigation water. Due to the lack of information about distributed recharge in the study area, the recharge value was taken from literatures.

[1] [11] used the recharge value of $200 \mathrm{~mm} /$ year representing the young alluvial plain of their models about certain area in the Nile valley of Upper Egypt, this value is controlled by the top silty clay layer which vanishes in the desert areas. In the desert areas, the recharge value represents a portion of applied irrigation water. [12] assume the recharge represent $22 \%$ - 33\% from the total applied water in the desert areas of semi-arid regions. In this model, recharge value was calibrated as $2 \mathrm{~mm} /$ year in the young alluvial plain and $29 \%$ of the total extracted water in the desert areas.

\section{Model Calibration}

The calibration process typically involves calibrating to steady state and transient conditions. With steady-state simulations, there are no observed changes in hydraulic head with time for the field conditions being modeled. These simulations are needed to narrow the range of variability in model input data since there are numerous choices of model input data values, which may result in similar steady-state simulations. Models may be calibrated without simulating steady-state flow conditions, but not without some difficulty. So, calibration refers to the procedure of adjusting model parameters to match observed data. The model is then verified. Verification is the process of taking the calibrated model and testing it against an independent set of data without changing model parameters. Table 1 shows the initial and calibrated parameters for the modeled area.

The calibration in the steady state has been conducted through hydraulic head data as at 1990. Calibration target of this work is to calibrate the hydraulic conductivity and river bed vertical conductivities. The initial head necessary for transient model was extracted after steady state calibration. Calibration process produced an acceptable comparison between observed and calibrated heads (Figure 5).

Transient condition was simulated in the period from 1990 till 2013. The well abstractions were collected and assigned as annual extraction rate. Recharge also were varied from year to year depending on the irrigation water infiltrated to the aquifer.

As a result of calibrated regional model, acceptable agreement between the calculated and observed hydraulic heads were obtained (Figure 6).

\section{Predictive Scenarios}

The TMR prediction models were used to evaluate different possible future development scenarios for the study areas as an attempt to explore the response and sustainability of the aquifer under different extraction schemes. The predictive simulation time should not be extended into the future more than twice the period for which calibration data are available [13]. For all applied scenario, the ratio between recharge rate and extraction rate concerning the Quaternary Aquifer is keeping constant.

Table 1. The initial and calibrated parameters for the modeled area.

\begin{tabular}{ccc}
\hline Parameter & Initial value & Calibrated value \\
\hline Hyd. conductivity of silty clay layer $(\mathrm{m} / \mathrm{d})$ & $0.1-0.005$ & 0.8 \\
Hyd. conductivity of main aquifer unit $(\mathrm{m} / \mathrm{d})$ & $20-150$ & 55 \\
Vertical conductivity of river bed $(\mathrm{m} / \mathrm{d})$ & $0.1-0.009$ & 0.06 \\
Recharge in the flood plain & $0.1-2.2 \mathrm{~mm} /$ day & $29 \%$ of the total irrigation water \\
Recharge in the desert fringes & $20 \%-35 \%$ of the total irrigation water & 0.02 \\
Specific storage $\left(\mathrm{m}^{-1}\right)$ & 0.1 & 0.25 \\
Specific yield & 0.22 & \\
\hline
\end{tabular}




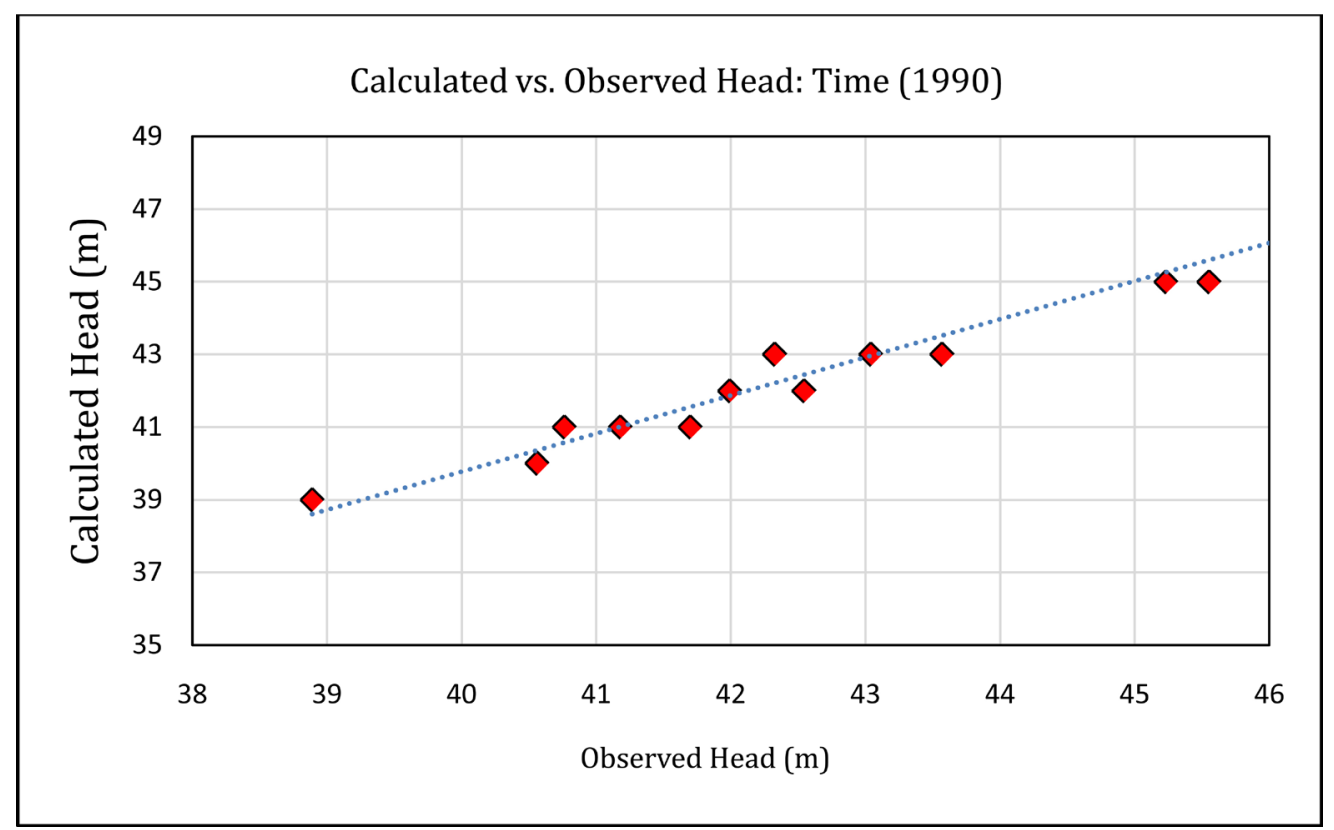

Figure 5. Calculated versus observed heads calibration for the steady state regional model by year 1990 .

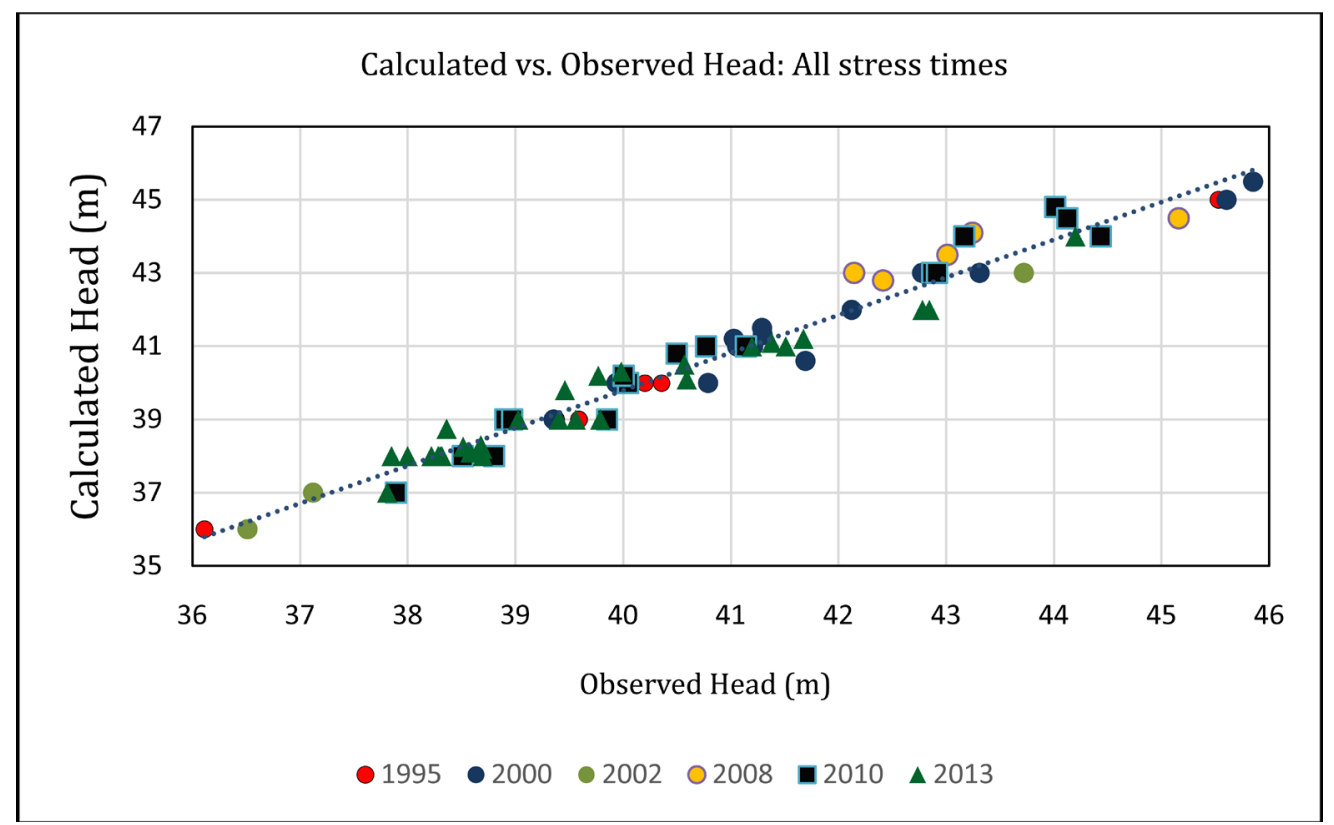

Figure 6. Calculated versus observed heads calibration for the transient regional model (1990-2013).

\subsection{Status Quo Scenario}

In this scenario, the present recharge rate as well as the extraction rate (according to end of 2013) are keeping constant during the prediction simulation time to evaluate the effect of the present status on the near future. The results of this scenario show that there is a considerable drawdown in hydraulic heads in all the modeled area increasing in the locations in which the pumping wells are concentrated and decrease far away resulted in forming cone of depression (COD) of elongated shape from north to south surrounding the major accumulation of pumping wells (Figure 7). Also, this drawdown decrease adjacent to the border of the fringes due to the continuous recharge by groundwater inflow through the eastern boundary of the all modeled area. This recharge increase by more pumping due to the increase in the hydraulic gradient between the eastern parts of the modeled 
area and adjacent areas outside the model.

Due to the above results and discussion of the aquifer response to this scenario, it can be concluded that present groundwater withdrawal from the QAS could not be safely predicted for more than 50 years and more scenarios should be applied for groundwater management.

\subsection{Carbonate Aquifer Feeding Scenario}

In the locations which Quaternary aquifer has low saturated thickness, Extract water by drilling wells in the Eocene Carbonate aquifer is predominant. These wells extract water from Eocene aquifer for agricultural purposes feeding the Quaternary aquifer.

In this scenario, the recharge from Eocene carbonate water was increased by quarter and half of the present rate as a response to the increase of new cultivated lands which depend on the Eocene carbonate water in the modeled areas.

The proposed location of recharge is divided up in the unreclaimed areas and promising areas for development especially in the western part of the study area considering that each feddan (acre) require $10-20 \mathrm{~m}^{3} /$ day and the total amount of recharge is approximately $3780-4200 \mathrm{~mm} /$ day per each feddan [14]. The resulted drawdown are shown in Figure 8.

This scenario is considered the most promising scenarios can be used as a way to groundwater management, the results of this scenario should be taking as a positive mark toward a groundwater management in the study area.

\section{Groundwater Management}

Groundwater operation policies aim at arriving at the most suitable conditions for groundwater abstractions. Several operational polices are designed and many simulation runs were carried out for different time periods in order to suggest a new strategy for the management of groundwater without critical depletion state. The main constraint imposed in the management policy is that the maximum drawdown of the groundwater heads should not exceed half the total saturated thickness of the aquifer at year 2013.

The results of the different scenarios applied show that the most optimum and safe groundwater extraction rate reaches $279,720 \mathrm{~m}^{3} /$ day which represents $180 \%$ of the present extraction rate. The resulted drawdown in

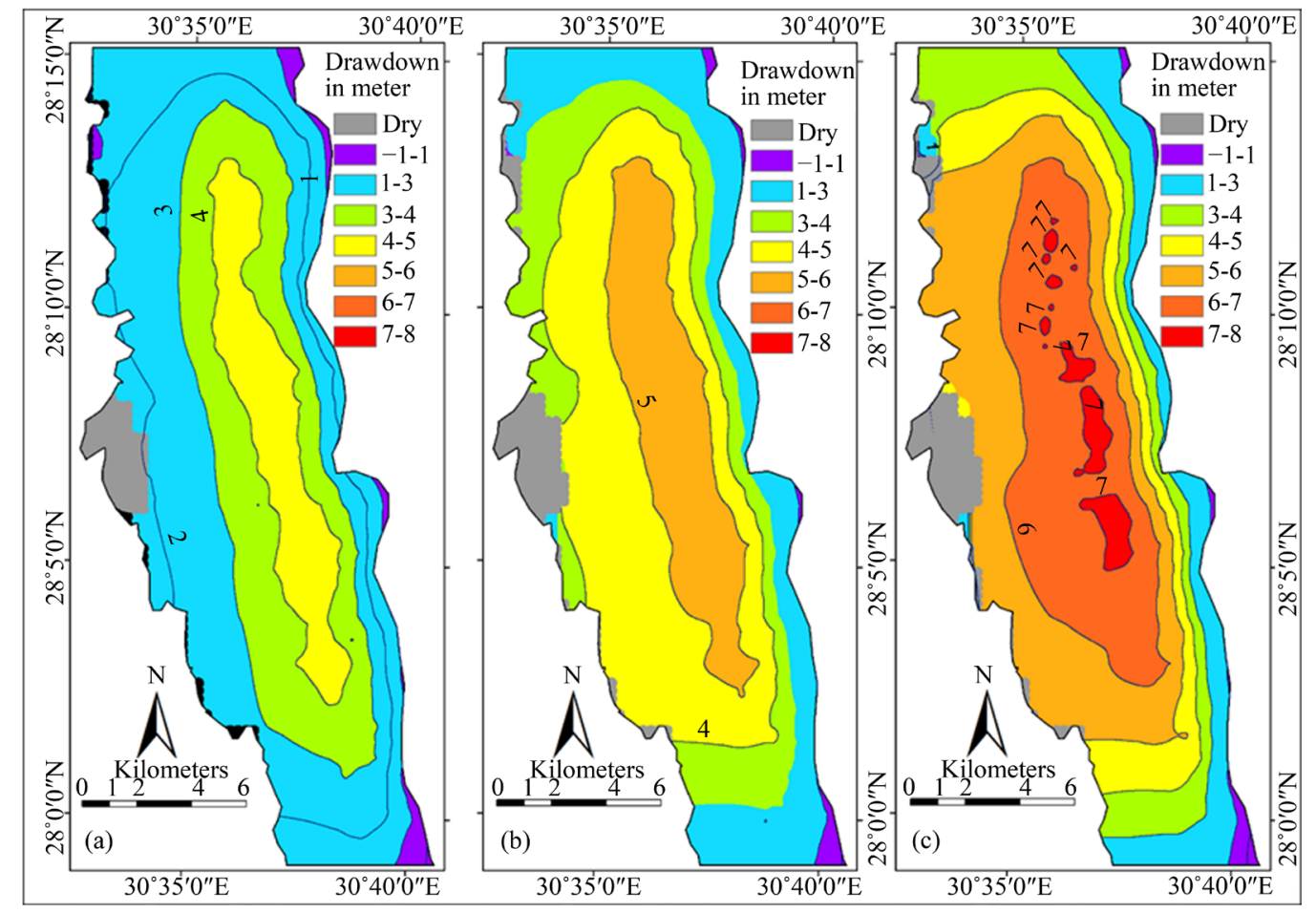

Figure 7. Predicted drawdown of the status Quo Scenario. (a) After 15 years; (b) After 30 years; (c) After 50 years. 


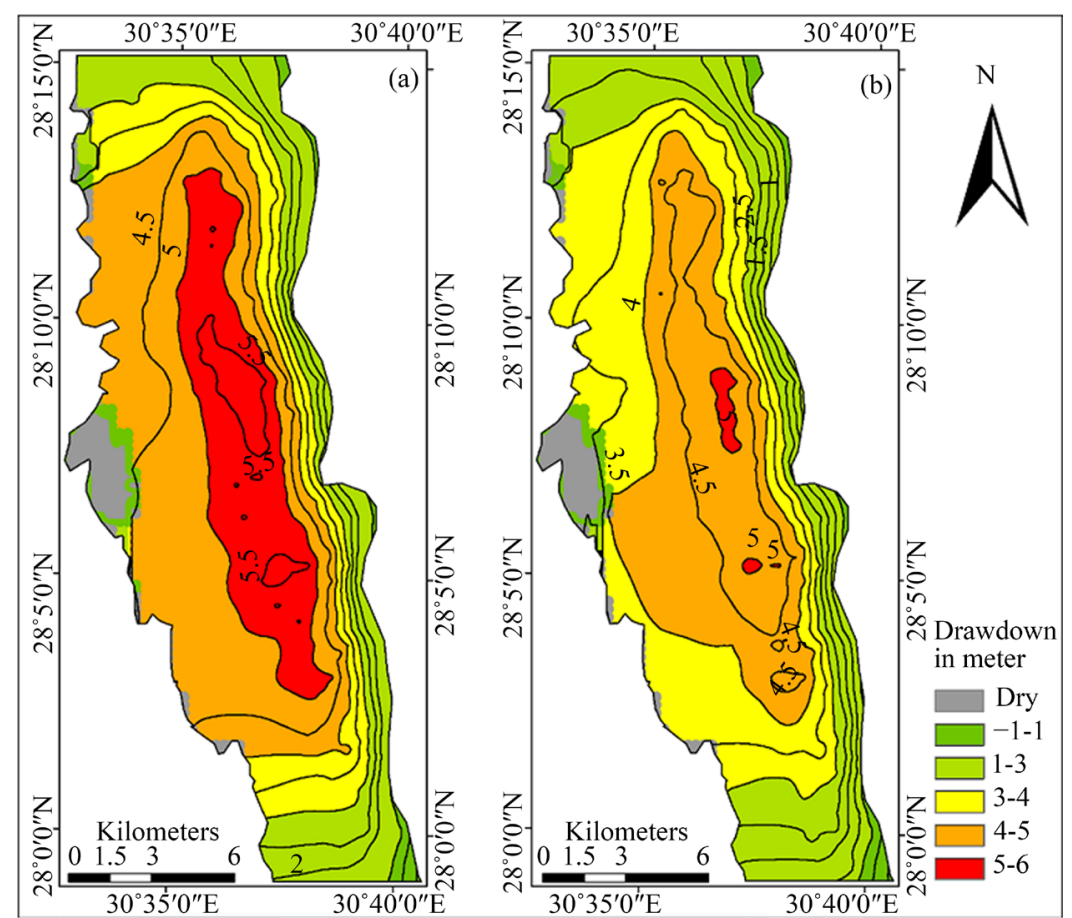

Figure 8. Predicted drawdown of the carbonate feeding scenario with (a) percent of $50 \%$ (b) percent of $100 \%$ of the present feeding rate.

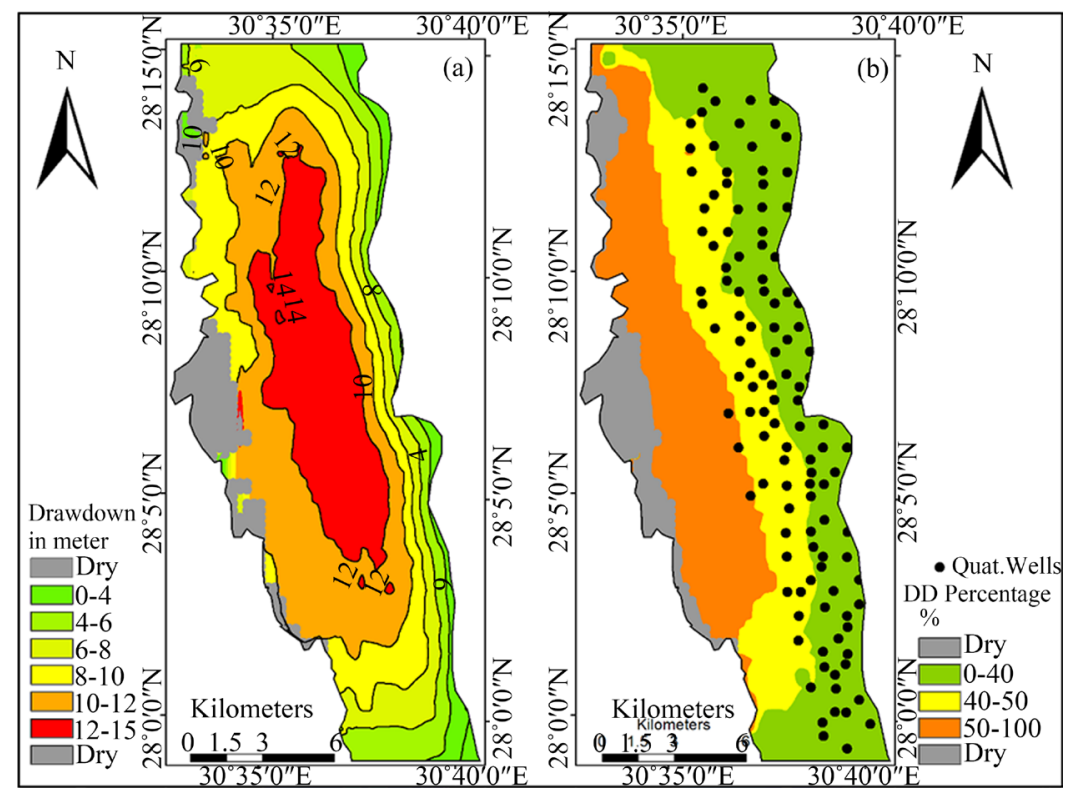

Figure 9. (a) The predicted drawdown and (b) the percentage of depletion from the saturated thickness after 50 years, resulted from applying the management scenario (extraction rate equal to $180 \%$ of the present Extraction rate).

case applying this extraction rate after 50 years are shown in Figure 9, while the drawdown in case applying 200\% of the present extraction rate is shown in Figure 10.

From the previous management scenarios and from the resulted maps, it is noticed that the most areas that are affected by groundwater withdrawal are those which are located in the western part of the studied areas. This is because near to the limestone plateau the quaternary aquifer has low saturated thickness and in some parts the aquifer is dry. 


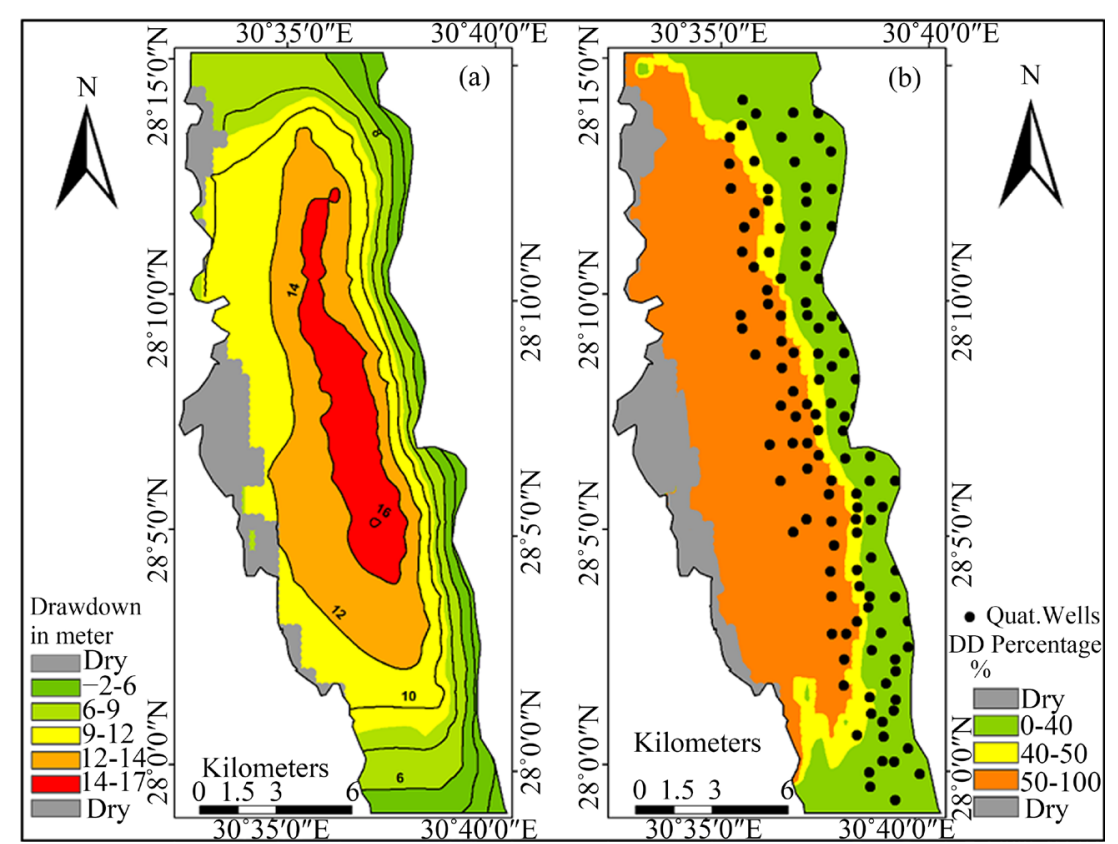

Figure 10. (a) The predicted drawdown and (b) the percentage of depletion from the saturated thickness after 50 years, resulted from applying extraction rate more than the management scenario (extraction rate equal to 200\% of the present Extraction rate).

Also, it should be emphasized here that it is recommended to drill the wells of Quaternary aquifer as far as possible from limestone escarpment because near to the plateau the water quality of the Quaternary aquifer is characterized be high dissolved solids as it affected by leaching sediments of the calcareous limestone of the plateau.

\section{Conclusion and Recommendations}

Groundwater is the most important source of water in the West El-Minia area for agricultural purposes. The increasing groundwater abstraction from the Quaternary aquifer resulted in a drop in the groundwater head. Heterogeneity plays an important role for groundwater flow in geological formations and needs to be accounted for in meaningful models. The most important conclusions can be stated as follows:

The present total amount of abstraction is about $155,400 \mathrm{~m}^{3} /$ day by 2013 and this value is higher than the leakage come from the Nile River and adjacent areas plus the recharge water come from irrigation. This may lead to annually decrease in the groundwater storage in the study area.

Drilling more wells that penetrate the carbonate aquifer plays an important role in the recharge of the Quaternary aquifer by applied water of irrigation. It can be stated a few recommendations as follows:

1) Any plan for increasing groundwater abstraction should be carefully performed.

2) Increase public awareness for proper use of ground water resources.

3) It is recommended to drill wells in the Eocene Carbonate aquifer because it makes as a recharge source for Quaternary Aquifer in the study area.

4) The total extraction rate per day should not excess $279,720 \mathrm{~m}^{3} /$ day in all of the study area for the upcoming 50 years in order to save the concerned aquifer from depletion.

\section{Acknowledgements}

Authors gratefully acknowledge the Egyptian agencies RIGWA and RIGW for their help and supporting with data. Deep thanks to the research group of Hydrogeophysics and NDT modeling unit, university of Oviedo, Spain for their help.

\section{References}

[1] Korany, E., Sakr, S., Darwish, M. and Morsy, S. (2006) Hydrogeologic Modeling for the Assessment of Continuous 
Rise of Groundwater Levels in the Quaternary Aquifer, Nile Valley, Egypt: Case Study. Proceedings of the 8th International Conference on the Geology of the Arab World (GAW8), Cairo University, July 2006, 703-711.

[2] Attia, F.A. (1974) Parameters and Characteristics of the Groundwater Reservoir in Upper Egypt. Ph.D. Thesis, Faculty of Engineering, Cairo University.

[3] Abou Heleika, M.M. and Niesner, E. (2008) Configuration of the Limestone Aquifers in the Central Part of Egypt Using Electrical Measurements. Hydrogeology Journal, 17, 433-446. http://dx.doi.org/10.1007/s10040-008-0360-8

[4] Said, R. (1997) The Geological Evolution of the River Nile. Springer-Verlag.

[5] Shabana, A.R. (2010) Hydrogeological Studies on the Area West Deir Mouas-Mallawi, El Minia Governorate, Egypt. Egyptian Journal of Geology, 54, 61-78.

[6] RIGW, Research Institute for Groundwater (1997) Hydrogeological Map of Egypt, Scale 1:1000,000. Map Sheet of El-Minia.

[7] RIGW/IWACO (1989) Development and Management of Groundwater Resources in the Nile Valley and Delta.

[8] Conoco Coral of Egypt (1987) Geologic Map of Egypt (Scale 1:500,000).

[9] RIGW, Research Institute for Groundwater (1992) Hydrogeological Map of Egypt, Scale 1:100,000. 2nd Edition, Map Sheet of El-Minia.

[10] McDonald, M. and Harbaugh, A.W. (1988) A Modular Three-Dimensional Finite Difference Ground-Water Flow Model. In: Techniques of Water-Resources Investigations, Book 6, U.S. Geological Survey, 588.

[11] Abdel Moneim, A.A. (1992) Numerical Simulation and Groundwater Management of the Sohag Aquifer, the Nile Valley, Egypt. Strathclyde University, Glasgow.

[12] Jimene-Martinez, J., Candela, L., Molinero, J. and Tamoh, K. (2010) Groundwater Recharge in Irrigated Semi-Arid Areas: Quantitative Hydrological Modelling and Sensitivity Analysis. Hydrogeology Journal, 18, 1811-1824. http://dx.doi.org/10.1007/s10040-010-0658-1

[13] Faust, C.R., Silka, L.R. and Mercer, J.R. (1981) Computer Modeling and Groundwater. Groundwater, 19, $362-365$. http://dx.doi.org/10.1111/j.1745-6584.1981.tb03480.x

[14] Barnes, J. (2012) Pumping Possibility: Agricultural Expansion through Desert Reclamation in Egypt. Social Studies of Science, 42, 517-538. http://dx.doi.org/10.1177/0306312712438772

\section{Submit or recommend next manuscript to SCIRP and we will provide best service for you:}

Accepting pre-submission inquiries through Email, Facebook, Linkedin, Twitter, etc

A wide selection of journals (inclusive of 9 subjects, more than 200 journals)

Providing a 24-hour high-quality service

User-friendly online submission system

Fair and swift peer-review system

Efficient typesetting and proofreading procedure

Display of the result of downloads and visits, as well as the number of cited articles

Maximum dissemination of your research work

Submit your manuscript at: http://papersubmission.scirp.org/ 